\title{
HABITAT USE OF THE PIÑON MOUSE (PEROMYSCUS TRUEI) IN THE TOIYABE RANGE, CENTRAL NEVADA
}

\author{
Aimee L. Massey ${ }^{1}$, Eric A. Rickart ${ }^{2}$, and Rebecca J. Rowe ${ }^{3}$
}

\begin{abstract}
Piñon-juniper woodland is expanding across much of western North America. In the Great Basin, woodland expansion has encroached on native shrublands, threatening species that have close associations with the sagebrush ecosystem. Piñon-juniper woodlands also harbor great biodiversity, and the response of woodland specialists to expansion has been less well studied than that of shrubland specialists. Here, we use occupancy and abundance modeling, accounting for imperfect detection, to assess habitat use of a woodland specialist, the piñon mouse (Peromyscus truei). Our study occurred in the Toiyabe Range of central Nevada, an area P. truei is thought to have recently colonized. Understanding habitat use at an expanding range margin can have important implications for dispersal-mediated woodland expansion. Peromyscus truei was documented in a wide range of conditions, including nonwoodland and woodland habitats, across the latitudinal and elevational extent of the mountain range. Occupancy models suggest that $P$. truei occurrences are most associated with the presence of piñon pine. For abundance, our global model was the best supported, indicating that no one environmental factor or set of factors considered were found to structure abundance. Chi-square tests indicate that use of woodland versus nonwoodland habitats by $P$. truei is not structured by age or sex. Although $P$. true $i$ was found in a range of habitat types, we cannot conclude whether it is more appropriate to characterize this species as a habitat generalist, or whether postcolonization abiotic and biotic filtering is not yet complete. Research on woodland specialists at expanding local and landscape-scale range margins provides a unique opportunity to study how habitat selection and ecological filtering impact community assembly under environmental change.
\end{abstract}

Resumen.-El bosque de piñón-junípero se está expandiendo hacia gran parte del oeste de América del Norte. En la Gran Cuenca (Great Basin), la expansión del bosque ha invadido los matorrales nativos, amenazando a las especies que están relacionan estrechamente con el ecosistema de artemisa. Los bosques de piñón-junípero albergan una gran biodiversidad y la respuesta de las especies especialistas de bosques en expansión ha sido menos estudiada que la de las especialistas en matorrales. Usamos modelos de ocupación y de abundancia, tomando en cuenta una detección imperfecta, para evaluar el uso del hábitat de un especialista de bosque, el ratón piñonero (Peromyscus truei). Nuestro estudio se llevó a cabo en la Cordillera Toiyabe al centro de Nevada, un área que se cree que $P$. truei colonizó recientemente. Entender el uso del hábitat en el límite del rango en expansión puede tener importantes repercusiones en la expansión del bosque, mediada por la distribución. Documentamos Peromyscus truei en una amplia gama de condiciones, incluyendo los hábitats boscosos y no boscosos, en toda la extensión latitudinal y altitudinal de la cordillera. Los modelos ocupacionales sugieren que la presencia de $P$. truei está estrechamente asociada a la presencia del pino piñonero. En cuanto a la cantidad, nuestro modelo global tuvo un mejor apoyo, indicando que no se encontró ningún factor ambiental o conjunto de factores que determinen la abundancia. Las pruebas de $\chi^{2}$ indican que el uso de hábitats boscosos frente al uso de hábitats no boscosos no se relaciona con la edad o el sexo de los individuos. A pesar de que encontramos $P$. truei en una variedad de hábitats, no podemos concluir que sea más apropiado caracterizar a esta especie como una especie generalista o que el filtro biótico y abiótico posterior a la colonización no se haya completado todavía. La investigación sobre los especialistas en bosques en los límites del rango local y del entorno en expansión, brinda una oportunidad única para estudiar cómo la selección del hábitat y el filtro ecológico afectan el ensamblaje de la comunidad cuando se dan cambios ambientales.

The Great Basin of western North America has witnessed a dramatic transformation over the past century, as climate change, land use, and invasive plant species have modified its native ecosystems (Noss et al. 1995, Wisdom et al. 2005, Chambers and Wisdom 2009, Morris and Rowe 2014). Among these changes, native bunchgrasses have given way to introduced perennial and annual invasive grasses (Knapp 1996, Novak and Mack 2001). Conversion to annual grasslands, along with associated altered fire regimes, has led to a decline in native shrublands (Whisenant 1990, Suring et al. 2005, Bradley 2010). Shrublands have also suffered losses to encroachment by native woodlands (Tausch et al. 1981, Miller

\footnotetext{
${ }^{1}$ Department of Fisheries and Wildlife, Oregon State University, 104 Nash Hall, Corvallis, OR 97331

${ }^{2}$ Natural History Museum of Utah, University of Utah, 301 Wakara Way, Salt Lake City, UT 84108.

${ }^{3}$ Corresponding author. Department of Natural Resources and the Environment, University of New Hampshire, 56 College Road, Durham, NH 03824. E-mail: rebecca.rowe@unh.edu
} 
and Rose 1999, Suring et al. 2005, Bradley 2010). The cumulative impacts of these effects are threatening the persistence of Great Basin native shrublands and their associated wildlife.

The expansion and infilling of piñon and juniper woodlands (Pinus monophylla, Juniperus osteosperma, and Juniperus occidentalis) is widespread (Miller and Rose 1999, Gray et al. 2006) and has been attributed to natural processes (recruitment and recovery from disturbance), changes in climate, and land use. Woodland expansion has been both upslope and downslope, but is greatest downslope, where it encroaches on shrublands (Tausch et al. 1981, Weisberg et al. 2007). Upslope expansion is often attributed to warming, whereas downslope expansion is primarily associated with land use, in particular livestock grazing and fire suppression (Miller and Wigand 1994, Miller and Rose 1999, Gray et al. 2006). However, climate may also be a facilitator of downslope expansion in areas experiencing increased precipitation (Bradley and Fleishman 2008) and where warmer temperatures modify winter thermal inversion layers (Billings 1954). Grazing can promote infilling and expansion of woodland by removing grasses and herbaceous cover that compete with seedlings, thereby suppressing fire by removal of fine fuels (Cottam and Stewart 1940, Miller and Wigand 1994).

Large-scale conversion of vegetation types can have profound impacts on wildlife, including changes in the distribution of species and community structure. This is especially the case in the Great Basin where many species, including some that are endemic to the region, have strong associations with shrubland and woodland ecosystems. Cheatgrass (Bromus tectorum), the most common of the invasive grasses in the Great Basin, has been shown to negatively impact the diversity and structure of bird and small mammal communities in shrubland habitats (Knick and Rotenberry 2000, Ostoja and Schupp 2009, Terry 2010, Freeman et al. 2014, Rottler et al. 2015). Similarly, woodland expansion has been associated with declines in occurrence and abundance of shrubland specialists (Noson et al. 2006, Larrucea and Brussard 2008, Rowe et al. 2010). Natural resource scientists and managers are working to reduce spread of invasive grasses and piñon-juniper woodlands to improve habitat for shrubland-obligate species (e.g., Rowland et al. 2006, Dumroese et al 2015, Bombaci and Pejchar 2016).

Piñon and juniper woodlands also harbor great biodiversity. These woodlands are one of the most extensive plant communities in western North America, occupying approximately 18 million hectares in the Intermountain Region (Miller and Tausch 2001), where they are the dominant cover type in the foothills upslope and adjacent to shrubland. These woodlands provide forage and habitat for many wildlife species. Obligate or semiobligate habitat associations have been well documented for many birds, as well as for bats and nonvolant mammals, including resident use by rodents and seasonal use by game species (Paulin et al. 1999, Pavlacky and Anderson 2001, Chung-MacCoubrey 2005, Anderson et al. 2012, Bombaci and Pejchar 2016).

Dispersal by animals mediates woodland expansion into shrub communities at local to landscape scales (Vander Wall and Balda 1981, Vander Wall 1997, Schupp et al. 1999). Numerous animals can move juniper berries and piñon pine seeds up to $1.6 \mathrm{~km}$ away from piñon-juniper woodland, and birds expand the dispersal distance up to approximately $5 \mathrm{~km}$ (Schupp et al. 1999, Suring et al. 2005). As such, studies of how woodland specialists select habitat can provide insight into their potential as agents of seed dispersal associated with woodland expansion. In addition, it is important to establish whether habitat quality is maintained for species associated with piñon and juniper under the changes in composition and structure that accompany the infilling, maturation, and expansion of woodland. Ultimately, understanding habitat selection of woodland specialists may provide an avenue for identifying conservation and management concerns (Rodhouse et al. 2010).

Here, we focus on the habitat use of Peromyscus truei, the piñon mouse, in the Toiyabe Range of central Nevada. This mouse inhabits arid and semiarid regions of the southwestern United States (Hoffmeister 1981) and has long been considered a habitat specialist with a particularly strong association with piñon pine and juniper vegetation on desert mountain ranges (Grinnell and Storer 1924, Hoffmeister 1951, 1981). Expansion of woodlands has recently been linked to elevational range shifts and increased abundance of P. truei 

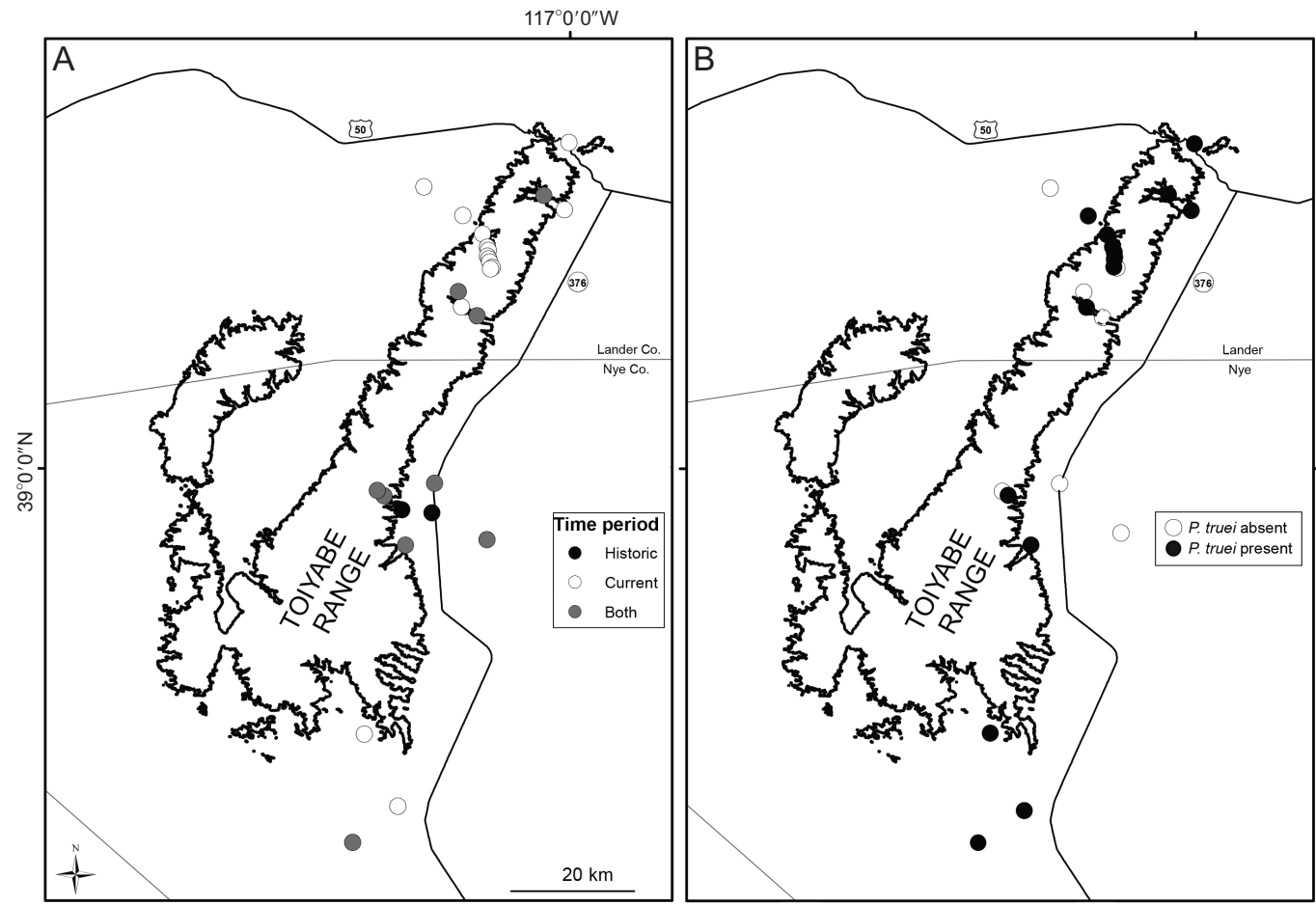

Fig. 1. Map of the Toiyabe Range, Nevada: A, the placement of survey sites during both the historic (1930-1931) and modern (2009-2011) time periods; B, the sites at which Peromyscuis truei was present or absent during the modern survey. Peromyscus truei was not detected at any sites historically.

elsewhere in the Great Basin (Rowe et al. 2010, 2011)

Although the geographic range of $P$. truei extends throughout much of the Great Basin, its occurrence in the Toiyabe Range is thought to be recent. The species was not detected in the range during a comprehensive mammal survey conducted in the early 1930s (Linsdale 1938). In contrast, recent surveys (Rowe and Terry 2014) documented $P$. truei along a broad latitudinal and elevational extent in this mountain range. This apparent recent colonization of the mountain range by $P$. true $i$, together with the spatial heterogeneity of the landscape, provides the opportunity to examine habitat use of this woodland specialist at an expanding range margin. Our objectives were to (1) identify the environmental factors correlated with the present-day occurrence and abundance of $P$. truei and (2) assess whether $P$. truei use of piñon-juniper woodland versus nonwoodland habitats was structured by age or sex, and thus reflective of natal dispersal pattern.

\section{Methods}

Study System and Field Surveys

During late spring to early autumn (MaySeptember) of 2009 to 2011, we conducted comprehensive surveys for nonvolant small mammals (shrews and rodents $<500 \mathrm{~g}$ ) at 24 sites in the Toiyabe Range of central Nevada (Fig. 1A). Conditions in this mountain range are generally arid due to the rain shadow of the Sierra Nevada; however, strong gradients of moisture and temperature are evident across elevations (Fig. 2). Low elevations are characterized by desert shrublands and alkali flats, and higher elevations contain birch, mountain mahogany, and limber pine. Piñonjuniper woodlands are most apparent at mid elevations between 1890 and $2440 \mathrm{~m}$. Survey sites were distributed across the latitudinal and elevational extent of the mountain range (Fig. 1A; ca. 38.45527 to $39.47530,1627 \mathrm{~m}$ to $2698 \mathrm{~m}$ ), with each site surveyed once during the 3-year period for a minimum of 500 trapnights (one trap set for one night) over at least 

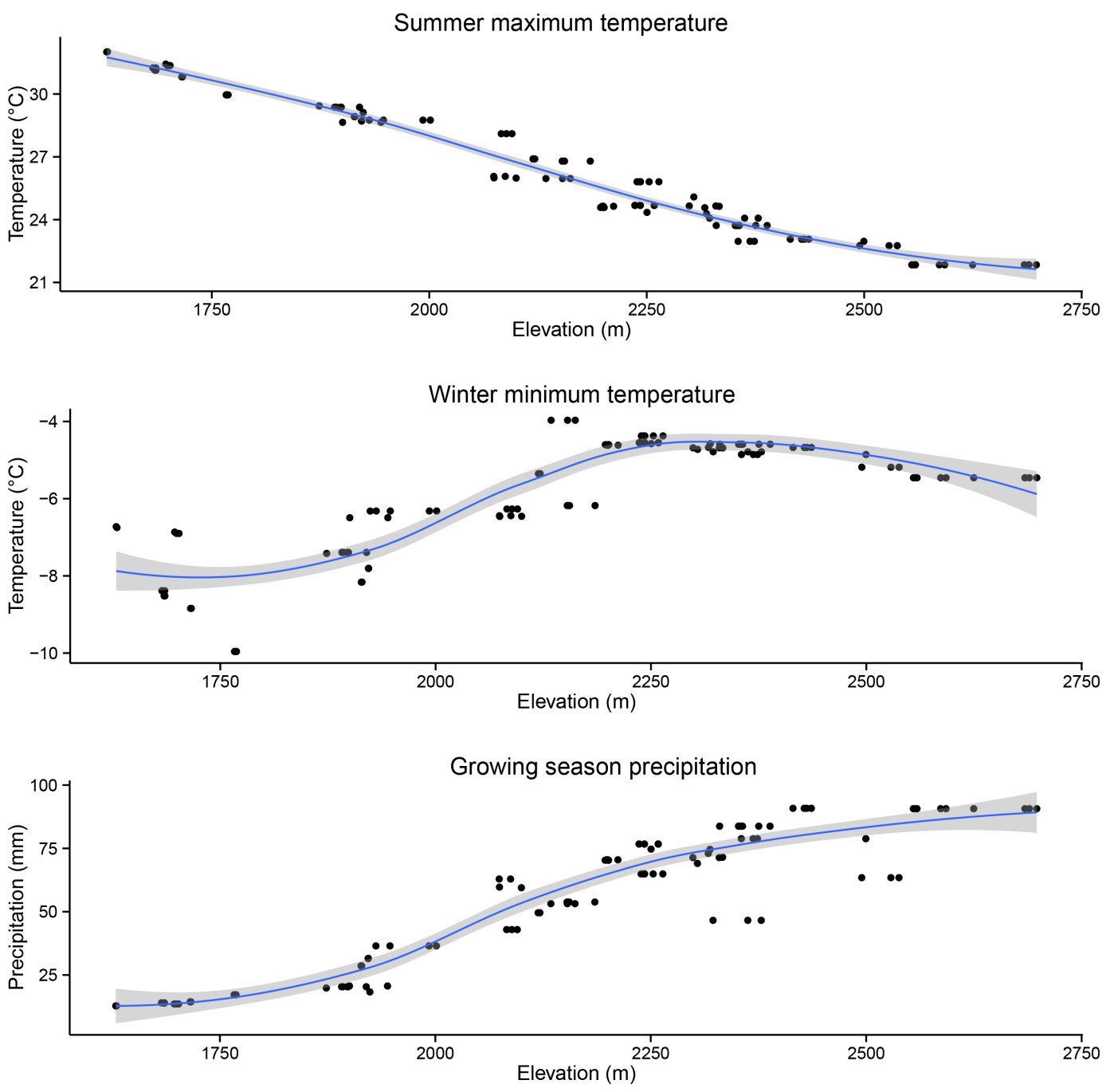

Fig. 2. Climate measurements along the elevational gradient. A positive linear relationship between elevation and each climate variable was demonstrated using locally weighted polynomial regression (loess) in the 'ggplot2' package (Wickham 2009) in R statistical computing environment. The climate data are average monthly values (800 m) from PRISM Climate Group. Values reflect the average across the respective months for a 6 -year period, the 3 survey years and the 3 years preceding the survey. Winter months are December through January, and summer months are June through August. Precipitation values are for the months of November through April (the rainfall associated with the following growing season).

4 consecutive nights. At each site, separate traplines were set within each discrete habitat type spanning the local moisture gradient (e.g., streamside riparian, shrubland, northfacing slope; Rowe et al. 2010) for a total of 102 traplines across the 24 sites. Trapline number varied per site because all habitat types were not present at all sites. Analyses were conducted at the trapline level, and detection estimates incorporated survey effort and removal trapping (see below). Vegetation surveys were conducted at 5 stations along each trapline, including each end and midpoint. At each station, percent cover was visually estimated within two $1-\mathrm{m}^{2}$ plots. Cover types included grass, forbs, woody plants, coarse woody debris, large rocks, and open ground. Dominant trees and shrubs within each trapline were also identified to species, and general habitat descriptions were 
included. A variety of trap types (i.e., Sherman live traps, Museum Special traps, and Victor rat traps) were used to ensure sampling of the entire small mammal community. All trapping was removal trapping, and each individual was identified to species, sexed, aged, weighed, measured, examined for reproductive condition, and prepared as a voucher specimen. Specimens and field notes were deposited in research collections at the Natural History Museum of Utah at the University of Utah; the Monte L. Bean Museum at Brigham Young University; the Field Museum of Natural History in Chicago, Illinois; and the Museum of Vertebrate Zoology at the University of California, Berkeley (Appendix 1). Fieldwork was conducted under multiple permits from the Nevada Department of Wildlife. Field procedures followed guidelines of the American Society of Mammalogists (Sikes et al. 2011) and were certified by the Animal Care and Use Committee of the University of Utah (0902004) and University of New Hampshire (111104A).

Our surveys totaled 15,080 trap-nights and yielded 3196 individuals representing 29 species of rodents and 4 species of shrews. Here, we focus on the occurrence and abundance of one species, Peromyscus truei. We captured P. truei at 16 of the 24 sites (Fig. 1B). A total of 81 individuals were captured, rendering $P$. truei the eighth most common of the 33 species surveyed. We used these counts as our abundance data.

Historical records from small mammal surveys carried out in the early twentieth century show that $P$. true $i$ was not documented in the Toiyabe Range at that time. Between 1930 and 1931, surveys were conducted at 12 sites for a total of 7536 trap-nights (Fig.1A) and yielded 1383 captures of 29 small mammal species, none of which were $P$. truei (Linsdale 1938, Rowe and Terry 2014). Two other Peromyscus species, P. maniculatus (deer mouse) and $P$. crinitus (cañon mouse), were captured at 11 and 3 sites, respectively. Our recent surveys included the resurvey of many of these historical localities (Fig. 1A). The historical surveys were comprehensive in effort and habitats surveyed, and employed methods that had the potential to capture P. truei. These historical records therefore serve as appropriate background sampling (Frey 2009) and suggest that $P$. true $i$ was not present in the
Toiyabe Range at that time. Furthermore, 178 additional small rodent specimens were collected at 10 locations in the Toiyabe Range between 1925 and 1935 (vertnet.org, searched on 22 August 2016), indicating that other surveys during this period also did not detect P. truei, and Hall (1946) did not report any records of $P$. truei from the Toiyabe Range. The closest historical record is from the "Reese River" (Osgood 1909), and consisted of a single specimen in the collection of the National Museum of Natural History that was obtained by Vernon Bailey on 18 May 1898 (NMNH 93408). Although the locality is imprecise, it is clear from Bailey's specimen records (https://collections.nmnh.si.edu/search/) that in May 1898 he was collecting as he moved south from the town of Austin toward Arc Dome in the southern Toiyabe Range and was in the Reese River valley immediately west of the range when he collected this specimen. Another historical record is a specimen collected on 12 July 1933 in Green Monster Canyon, Monitor Range, approximately $100 \mathrm{~km}$ southeast of the Toiyabe Range (MVZ 58381). A search of museum collection databases for P. truei from Nevada did not reveal any additional records from the Toiyabe region (vertnet .org, searched on 22 August 2016). These data show that $P$. truei was present but not abundant in central Nevada during the early 20 th century and support 2 possible historical scenarios within the Toiyabe Range: (1) P. truei was formerly absent and has subsequently colonized the range by moving across intervening lowlands or (2) $P$. truei was present but sufficiently rare (or geographically restricted) to have escaped detection in the past and has subsequently increased in abundance and experienced an in situ range expansion.

Photo comparisons illustrate the infilling and expansion of piñon-juniper woodland that has occurred in the Toiyabe Range over the 80 -year interval between these small mammal surveys (Fig. 3). Following the definitions of Miller et al. (2000, 2005), early-, mid-, and late-phase postsettlement woodland are evident in our images.

\section{Occupancy and Abundance Modeling}

To model occupancy and abundance, we utilized the "unmarked" package (Fiske and Chandler 2011) in the R statistical computing environment (R Core Team 2015) using the 


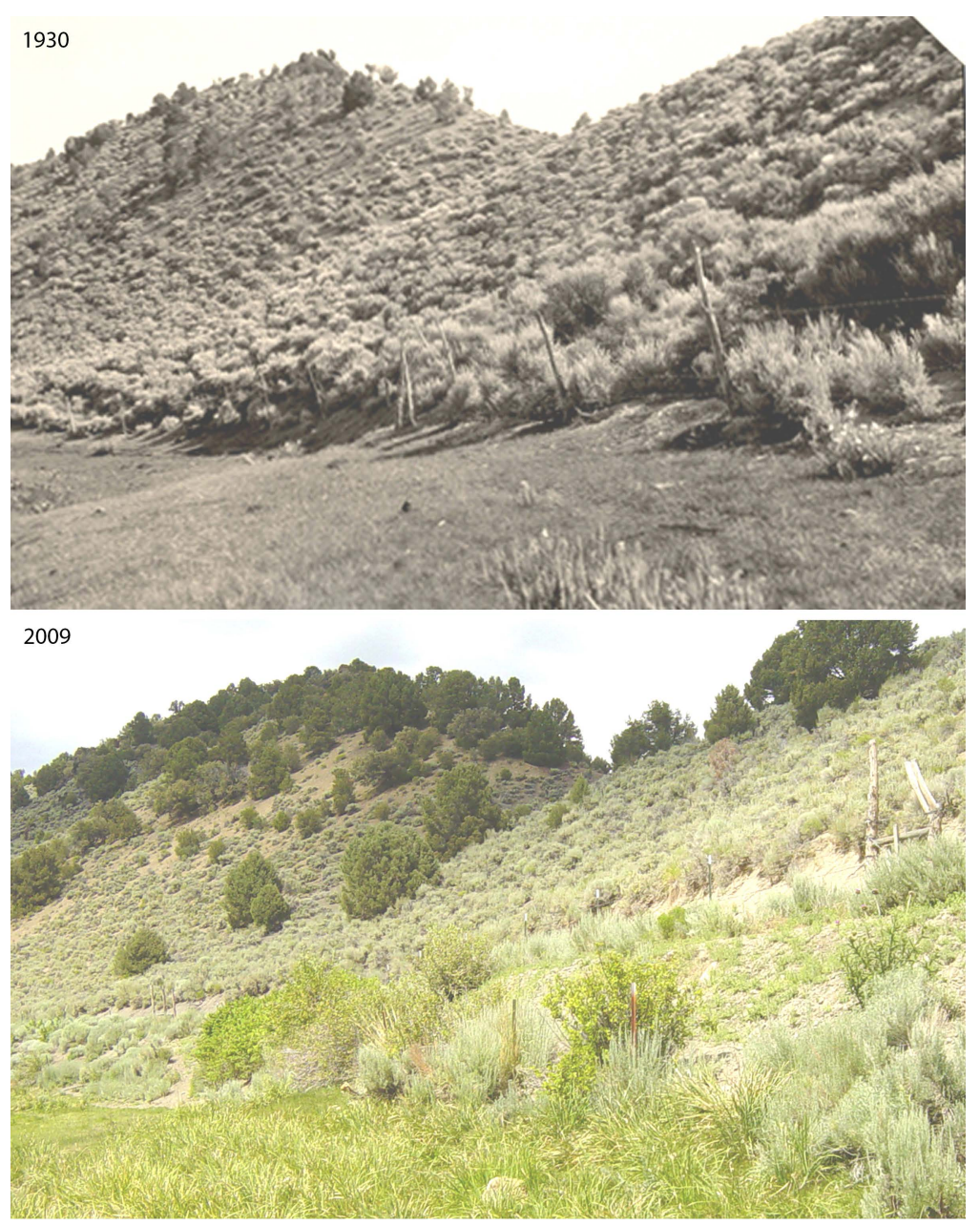

Fig. 3. Repeat photography showing vegetation change at a survey site in the Toiyabe Range, Nevada, over the approximately 80-year interval. The infilling and expansion of pinon-juniper woodland is evident. The site is located in Birch Creek Canyon at $7040 \mathrm{ft}$. (2146 m) elevation. The historical photo was taken by J.M. Linsdale in 1930 (courtesy of MVZ archives; Linsdale 1938) and the current photo by E.A. Rickart in 2009.

respective occupancy and abundance models described below. First, we accounted for imperfect detection of P. truei. To estimate detection probability for occupancy, we considered the following covariates: trap or survey effort (number of traps per trap night), Julian date (treated as both linear and quadratic), and trend (a linear change in detection over sequential nights to account for removal of individuals captured; Moritz et al. 2008). We built 12 detection models, considering each variable independently and in all additive combinations, as well as a null model (.). We ran each detection model with a null term for occupancy. For model selection we used
Akaike's information criterion (AIC) and determined the "best" detection model as the one with the lowest AIC score (Burnham and Anderson 2002). This detection model was then used in all of our occupancy models. Detection and occupancy estimates were calculated from the null model using the "backTransform" function in package "unmarked." Similarly, to estimate detection probability for abundance, we accounted for the independent variables of trap effort and Julian date (treated as both linear and quadratic). We built 6 detection models representing all additive combinations of these variables as well as a null model (.). We ran each detection model 
with a null term for abundance and selected the best-supported detection model (the model with the lowest AIC score) to be used in all of our abundance models. All detection models are summarized in Appendix 2.

For occupancy and abundance we evaluated the same set of 19 competing a priori models (Appendix 3). These models varied only in their incorporation of the detection component. Occupancy was modeled using a binomial model with a logit link ("occu" function), and abundance was modeled using a multinomial-Poisson mixture model ("multinomPois" function) to account for removal sampling. These models are based on our understanding of the species biology and published accounts on habitat suitability that suggest that $P$. truei elsewhere in the Intermountain West predominately uses woodland sites with bare ground cover and dry, rocky slopes (Rompola and Anderson 2004, Rodhouse et al. 2010). Steep slopes are often associated with rocky substrate. The models incorporated the following 6 variables: year, presence of piñon-juniper woodland, percent cover of woody shrub (predominately sagebrush), slope, aspect, and elevation. We interpret variation in occupancy and abundance across sites to reflect variation in the suitability of conditions, such that higher occupancy and abundance reflect higher habitat quality (but see Van Horne 1983). Preliminary analyses indicated that the form of the relationship for elevation was a linear function for occupancy and a quadratic function for abundance. We used the simpler linear model unless the quadratic model was a better fit, as measured by an AIC score $>4.159$ (equivalent to an evidence ratio of 8), representing strong evidence supporting one hypothesis over another (Royall 1997, Burnham and Anderson 2002). Cover of woody shrub ranged from $12.5 \%$ to $69.6 \%$. Slope and aspect were taken from a digital elevation model (DEM) using ArcGIS v10.2 and varied from 0.09 to 38.09 and 6.97 to 350 , respectively. Aspect was converted to radians and then cos- and sin-transformed to yield northness and eastness, respectively. We investigated 3 climate parameters (summer maximum temperature, winter minimum temperature, and total precipitation), drawing data from high-resolution (800-m) monthly grids (PRISM Climate Group) for the 3 years of the survey and the 3 preceding years. These variables were not included in the models because they were highly collinear with elevation $\left(R^{2}{ }_{\max T}=0.9576, R^{2}{ }_{\operatorname{minT}}=0.5659\right.$, $R_{\text {precip }}^{2}=0.8535$; see Fig. 2 ).

We use AIC to evaluate the strength of evidence for preferential use among sites based on the factors included. The competing models were fit and ranked based on the lowest AIC score, and those with the lowest AIC score were considered the best at describing the data. When multiple models received a $\triangle \mathrm{AIC}<2$, we employed model averaging using the "model.avg" function in the "MuMIn" package (Bartoń 2015) to better determine which covariates were important predictors (Arnold 2010). Under model averaging, parameters were interpreted as uninformative $(P>$ $0.05)$ if the $95 \%$ confidence intervals included zero.

Lastly, we conducted chi-square tests to assess whether the abundance of $P$. truei in sites with and without piñon-juniper woodland was structured by age and/or sex and may therefore reflect male-biased natal dispersal often associated with mammals (Greenwood 1980). Peromyscus truei is thought to be closely associated with piñon-juniper woodland (Grinnell and Storer 1924, Hoffmeister 1951), and given the variety of habitats surveyed, we set out to determine if young males were dispersing into non-piñon-juniper woodland significantly more than other individuals. All individuals were categorized as either adult or immature based on body size, developmental molt state, and reproductive condition (e.g., testes position and size for males; nipple size, vaginal perforation, and uterine condition for females).

\section{RESULTS}

Peromyscus truei was captured at 24 of the 102 traplines and distributed across 16 of the 24 sites (Fig. 1b). These 16 sites included both the lowest $(1627 \mathrm{~m}$ ) and highest $(2698 \mathrm{~m})$ in elevation and the most southern and northern of those surveyed. Local small mammal diversity at these 16 sites ranged from 5 to 15 species. The relative abundance of $P$. true $i$ at these sites ranged from $0.05 \%$ to $10.5 \%$, with rank abundance of $P$. true $i$ as the least abundant to second most abundant species. The climate conditions at these 16 sites where $P$. truei was captured ranged from $-8.16{ }^{\circ} \mathrm{C}$ to 
TABLE 1. Summary statistics for all occupancy models with $\Delta$ AIC $<2$. Predictor variables included presence of pinon-juniper woodland (PJ), percent cover of woody shrub (woody), elevation (elev), survey year (year), slope (slope), and aspect (aspect) measured as the $\cos$ (radians) and the $\sin$ (radians). The best-fit detection model was incorporated in each (see Appendix 2). $\mathrm{K}=$ number of parameters, AIC $=$ Akaike information criterion, $\Delta \mathrm{AIC}=$ model AIC difference, AIC wt $=$ model Akaike weight. Cumulative weight across these 6 models is 0.86 .

\begin{tabular}{|c|c|c|c|c|}
\hline Model & $\mathrm{K}$ & $\mathrm{AIC}$ & $\Delta \mathrm{AIC}$ & AIC wt \\
\hline psi $($ elev + PJ + woody + year $) p($ trapdays + trend $)$ & 9 & 208.25 & 0.00 & 0.20 \\
\hline psi(year+PJ+woody)p(trapdays + trend $)$ & 8 & 208.53 & 0.28 & 0.17 \\
\hline psi(PJ+ woody)p(trapdays + trend $)$ & 6 & 208.69 & 0.44 & 0.16 \\
\hline $\operatorname{psi}(\mathrm{PJ}) \mathrm{p}($ trapdays + trend $)$ & 5 & 209.04 & 0.79 & 0.13 \\
\hline psi(elev + PJ + woody)p(trapdays + trend $)$ & 7 & 209.58 & 1.33 & 0.10 \\
\hline psi(elev + PJ)p(trapdays + trend $)$ & 6 & 209.61 & 1.37 & 0.10 \\
\hline
\end{tabular}

TABLE 2. Summary results of the model averaging for occupancy. The first 6 models (those with $\Delta$ AIC $<2$; Table 1 ) were included. Parameters were interpreted as uninformative $(P>0.05)$ if the $95 \%$ confidence intervals included 0.

\begin{tabular}{lrccc}
\hline Parameter & Estimate & SE & $z$ value & $\operatorname{Pr}(>|z|)$ \\
\hline psi(Int) & -1.1005 & 0.3708 & 2.968 & $0.00300^{* *}$ \\
psi(PJ) & 1.0743 & 0.3821 & 2.811 & $0.00494^{* *}$ \\
psi(woody) & 0.4473 & 0.3261 & 1.372 & 0.17016 \\
p(Int) & -0.9963 & 0.7422 & 1.342 & 0.17944 \\
p(trapdays) & 0.0265 & 0.0126 & 2.102 & $0.03552^{*}$ \\
p(trend) & -0.2943 & 0.2088 & 1.409 & 0.15873 \\
psi(year1) & -0.6527 & 0.5150 & 1.268 & 0.20496 \\
psi(year2) & 0.4727 & 0.5350 & 0.884 & 0.37694 \\
psi(elev) & -0.4339 & 0.3630 & 1.195 & 0.23199 \\
\hline
\end{tabular}

$* P<0.05$

$* * P<0.01$

$-4.37{ }^{\circ} \mathrm{C}$ for winter minimum temperature, from $21.84{ }^{\circ} \mathrm{C}$ to $32.01{ }^{\circ} \mathrm{C}$ for summer maximum temperature, and from 12.81 to $90.83 \mathrm{~mm}$ of precipitation. Piñon-juniper was present at 11 of the 24 survey sites, and at 24 of 46 traplines within those sites. More specifically, piñon-juniper was present at 9 of the 16 sites and 13 of the 24 traplines where $P$. true $i$ was captured. These captures of $P$. truei accounted for 63 of the 81 individuals, 47 of which were adult. The remaining 18 individuals were captured across 7 sites among 11 traplines on desert pavement, in sagebrush, on rocky outcrops, among willows, and under aspen. Captures were distributed across the 3 survey years: 3 in 2009, 15 in 2010, and 63 in 2011.

The covariates trap effort [trapdays] and trend best described detection for occupancy (Appendix 2) and were used for all occupancy models (Table 1). We found that none of our 19 occupancy models received strong support. The model described by the variables piñon-juniper woodland, woody vegetation, year, and elevation received the highest of the AIC weights at 0.20 , and 6 models had values of $\Delta$ AIC $<2$ (Table 1). Unnested models with $\Delta$ AIC $<2$ are often considered equivalent
(Burnham and Anderson 2002, Arnold 2010), and for this reason we model-averaged these first 6 models to better account for model selection uncertainty in assessing the most important factors in structuring the occupancy of $P$. truei. We found the presence of piñonjuniper to be the only factor significantly correlated with the occurrence of $P$. truei, with an average trend value of 1.07 (Table 2). Detection and occupancy estimates were 0.386 (SE 0.07) and 0.29 (SE 0.571), respectively.

The covariates trap effort and Julian date best described detection for abundance (Appendix 2) and were used for all abundance models (Table 3). We found that the global model (i.e., the most complicated abundance model), including the covariates of pinonjuniper woodland, woody vegetation, year, slope, aspect, and elevation, was the best-fit model describing $P$. truei abundance from our set of 19 a priori-selected models (Table 3, Appendix 3). This model received an AIC weight of 1.00 (Table 3).

Our chi-square tests failed to show any dependence of age and sex on the abundance of $P$. truei in non-piñon-juniper woodland $\left(\chi^{2}\right.$ $=2.777, \mathrm{df}=3, P=0.4272)$. Because sample 
TABLE 3. Summary statistics for the top 6 abundance models (ranked by $\Delta$ AIC). Predictor variables included presence of pinon-juniper woodland (PJ), percent cover of woody shrub (woody), elevation squared $\left(\mathrm{elev}^{2}\right)$, survey year (year), slope (slope), and aspect (aspect) measured as the $\cos$ (radians) and the $\sin$ (radians). The best-fit detection model was incorporated in each (see Appendix 2). $\mathrm{K}=$ number of parameters, AIC $=$ Akaike information criterion, $\Delta \mathrm{AIC}=$ model AIC difference, AIC wt = model Akaike weight.

\begin{tabular}{|c|c|c|c|c|}
\hline Model & $\mathrm{K}$ & $\mathrm{AIC}$ & $\Delta \mathrm{AIC}$ & AIC wt \\
\hline $\operatorname{lam}\left(\mathrm{PJ}+\right.$ woody + elev + elev $^{2}+$ year + slope + aspect $) \mathrm{p}($ trapdays $+\mathrm{jd})$ & 13 & 343.99 & 0.00 & 1.00 \\
\hline $\operatorname{lam}\left(\right.$ elev + elev $^{2}+$ PJ + woody + year $) p($ trapdays $+\mathrm{jd})$ & 10 & 364.39 & 20.46 & $3.6 \times 10^{-5}$ \\
\hline $\operatorname{lam}\left(\right.$ elev + elev $\left.^{2}+\mathrm{PJ}\right) \mathrm{p}($ trapdays $+\mathrm{jd})$ & 7 & 368.86 & 26.50 & $3.9 \times 10^{-6}$ \\
\hline $\operatorname{lam}\left(\right.$ elev + elev$^{2}+\mathrm{PJ}+$ woody $) \mathrm{p}($ trapdays $+\mathrm{jd})$ & 8 & 370.42 & 32.56 & $1.8 \times 10^{-6}$ \\
\hline $\operatorname{lam}($ year + PJ + woody $) \mathrm{p}($ trapdays $+\mathrm{jd})$ & 8 & 376.48 & 37.78 & $8.5 \times 10^{-8}$ \\
\hline $\operatorname{lam}(\mathrm{PJ}) \mathrm{p}($ trapdays $+\mathrm{jd})$ & 5 & 381.71 & 39.44 & $6.2 \times 10^{-9}$ \\
\hline
\end{tabular}

size was low in non-piñon-juniper woodland (18 individuals), we carried out further chisquare tests, categorizing individuals based on either age or sex. However, we found no evidence of dependence between age and habitat $\left(\chi^{2}=2.4361, \mathrm{df}=1, P=0.1186\right)$ or sex and habitat $\left(\chi^{2}=0.176, \mathrm{df}=1, P=0.6748\right)$.

\section{Discussion}

Our field surveys indicate that $P$. truei is currently widespread throughout the Toiyabe Range, occurring at approximately 66\% (16 of 24) of the sites sampled, including the lowest and highest in elevation and the most southern and northern of the sites surveyed (Fig. 1B). Within these 16 sites, P. truei was never captured in all habitat types (i.e., discrete traplines) surveyed. This suggests that at the local scale, competition or niche requirements play a role in species assortment. Although $P$. truei was captured in a variety of habitat types, including those with and without piñonjuniper, our occupancy models indicate that presence of piñon-juniper woodland was the most significant predictor of $P$. truei presence. This finding is consistent with previous studies in the Intermountain West indicating that $P$. truei is primarily associated with piñon-juniper and juniper woodland habitats (Holbrook 1978, Hoffmeister 1981, Carraway et al. 1993, Rompola and Anderson 2004, Rodhouse et al. 2010). For abundance, the global model received the strongest support, indicating that with the environmental factors considered we could not detect variation in suitability among the habitats in which P. truei occurred. Additional studies would be needed to assess the fitness or dominance of individuals relative to their habitat use. Results from our chi-square tests indicate that the occurrence of $P$. true $i$ at localities outside of piñon-juniper woodland is not restricted to young males dispersing into or across marginal habitats. Overall, our results suggest that within the Toiyabe Range, there are resident populations of $P$. truei in piñonjuniper woodland and in diverse habitat types without piñon or juniper.

Recent changes in climate and habitat suitability have impacted the distribution of P. truei in western North America. In the Sierra Nevada, P. truei has recently expanded its range upslope, tracking climate into a new habitat of subalpine coniferous forest (Moritz et al. 2008, Yang et al. 2011). Recent occurrence of $P$. truei among high-elevation pine has also been documented in the Snake Range, eastern Nevada (Rickart et al. 2008). Our study also showed $P$. truei occurring at elevations above the pinon-juniper belt. However, climate warming is unlikely to contribute to the occupancy of diverse habitat types at lower elevations. Recent studies have shown P. truei to expand its elevational range both upslope (Moritz et al. 2008) and downslope (Rowe et al. 2010), tracking its preferred habitat as that habitat zone has expanded in response to changes in the environment and management practices. An expanding habitat zone likely brings $P$. truei in closer proximity to a wider range of habitat types than previously encountered, thus facilitating opportunity for broad habitat use. Broad habitat use also suggests that $P$. truei may facilitate woodland expansion via dispersal over greater distances than currently considered.

Declines in the suitability or availability of a preferred habitat type may also promote broad habitat use. This can occur directly, through reduced habitat quality, or indirectly, through the limitation of resources driven by competition when density is high. 
For many wildlife species that use piñon and juniper woodlands, the composition of the understory plays an important role in habitat suitability (Willis and Miller 1999, Rodhouse et al. 2010). The infilling of woodlands and subsequent decrease in the herbaceous understory may negatively impact habitat quality for $P$. truei, thus facilitating expansion into adjacent or more marginal habitat types. If this is the case, woodland reduction treatments may improve conditions for $P$. true $i$ as well as shrubland-associated species, assuming reduction efforts encourage shrub and native grass recovery, which has not been conclusively determined (Bombaci and Pejchar 2016). Some studies have found P. truei to respond positively to thinning treatments (reviewed in Bombaci and Pejchar 2016), but current studies are limited, and the impact of removal treatments on small mammals is largely inconclusive given different removal methods and variation in stand age, timing of assessment postremoval, and the taxonomic or functional group under study (Willis and Miller 1999, Bombaci and Pejchar 2016).

Previous studies have shown $P$. truei to use woodlands with well-developed canopies and secondarily bare or sparsely vegetated understories (Rompola and Anderson 2004, Rodhouse et al. 2010). Although we did not measure woodland canopy cover, our vegetation surveys indicate that $P$. true $i$ is no more or less likely to occur in (or be abundant within) a sparsely or more densely vegetated understory community. Our models indicated presence of piñon-juniper woodland to be the only factor correlated with $P$. truei occupancy; percent cover of woody shrub did not have a positive or negative effect on $P$. truei occurrence or abundance. Among the traplines containing piñon-juniper, percent cover of woody shrub ranged from $12.5 \%$ to $46.5 \%$ and was negatively correlated with bare ground $\left(R^{2}=\right.$ 0.72 ). These percent cover data indicate that $P$. true $i$ is tolerant of diverse ground conditions and may suggest that neither occupancy nor abundance responds strongly to variation in canopy structure.

Habitat use is assessed by the distribution and relative abundance of a species across habitat types and is shaped by the exogenous factors of dispersal and colonization and by the endogenous factors of intrinsic population growth, competition, and predation (Fretwell and Lucas 1969, Rosenzweig 1981, Morris 1988, Resetarits 2005, Burgess et al. 2012). Our survey data suggest that $P$. true $i$, a species often considered a woodland specialist, has recently expanded into the Toiyabe Range and occupies both woodland and nonwoodland habitat across the latitudinal and elevational extent of the mountain system. This expansion may reflect successful dispersal across lowland valley habitat. We find that piñon-juniper woodland continues to play a critical role in the distribution of $P$. true $i$ and that woodland expansion has likely facilitated range expansion within the Great Basin. Species may traverse large distances to follow shifts in suitable climate and habitat. Long-distance dispersal is facilitated by patches of suitable habitat scattered across the landscape and by exploitation of matrix conditions not considered to be preferred habitat. While our findings suggest broad use of habitat conditions by $P$. truei, we cannot directly address whether $P$. true $i$ would be more aptly considered a habitat generalist or whether postcolonization abiotic and biotic filtering is not yet complete. Over time, postcolonization endogenous processes may modify or erase patterns of habitat use established during the colonization process (e.g., Morin 1984, Vonesh et al. 2009, Morris 2011). The broad use of habitats by $P$. truei detected by our survey may reflect the legacy of a shift in habitat selection associated with a presumably recent and rapid colonization event, which may or may not persist under postcolonization processes. Expanding range margins under environmental change offer a unique opportunity to study habitat selection, the ecological processes of abiotic and biotic filtering, and the effect of these processes on community assembly.

\section{ACKNOWLEDGments}

This work was supported by National Science Foundation Grants DEB 0919409 and DEB 1457530, the University of Utah, and the University of New Hampshire. Fieldwork was conducted under permits from the Nevada Division of Wildlife. We are grateful to the Museum of Vertebrate Zoology, University of California, Berkeley, for preservation of and access to the historical material. For their help with fieldwork, we thank Lois Alexander, Anthony Bell, Brett Hellstrom, 
Austin Higginson, Kevin Kohl, Carina Maron, Lorie Millward, Carol Patton, Jim Patton, Shannen Robson, and Duke Rogers. We also thank Dan Hocking for providing analytical advice. Comments from 3 anonymous reviewers improved the quality and clarity of this work.

\section{Literature Cited}

Anderson, E.D., R.A. Long, M.P. Atwood, J.G. Kie, T.R. Thomas, P. Zager, AND R.T. Bowyer. 2012. Winter resource selection by female mule deer Odocoileus hemionus: functional response to spatio-temporal changes in habitat. Wildlife Biology 18:153-163.

ARNOLD, T.W. 2010. Uninformative parameters and model selection using Akaike's information criterion. Journal of Wildlife Management 74:1175-1178.

BARTOŃ, K. 2015. MuMIn: multi-model inference. R package version 1.15.1.

BiLlings, W.D. 1954. Temperature inversions in the pinyon-juniper zone of a Nevada mountain range. Butler University Botanical Studies 11:112-117.

Bombaci, S., and L. Pejchar. 2016. Consequences of pinyon and juniper woodland reduction for wildlife in North America. Forest Ecology and Management 365:34-50

Bradley, B.A. 2010. Assessing ecosystem threats from global and regional change: hierarchical modeling of risk to sagebrush ecosystems from climate change, land use and invasive species in Nevada, USA. Ecography 33:198-208.

Bradley, B.A., and E. Fleishman. 2008. Relationships between expanding pinyon-juniper cover and topography in the central Great Basin, Nevada. Journal of Biogeography 35:951-964.

Burgess, S.C., E.A. Treml, and D.J. Marshall. 2012. How do dispersal costs and habitat selection influence realized population connectivity? Ecology 93:1378-1387.

Burnham, K.P., AND D.R. ANDERSON. 2002. Model selection and multimodel inference: a practical informationtheoretic approach. 2nd edition. Springer, New York, NY.

Carraway, L.N., E. Yensen, B.J. Verts, and L.F. AlexanDER. 1993. Range extension and habitat of Peromyscus truei in eastern Oregon. Northwestern Naturalist 74:81-84.

Chambers, J.C., And M.J. Wisdom. 2009. Priority research and management issues for the imperiled Great Basin of the western United States. Restoration Ecology 17:707-714.

Chung-MacCoubrey, A.L. 2005. Use of pinyon-juniper woodlands by bats in New Mexico. Forest Ecology and Management 204:209-220.

Cottam, W.P., and G. Stewart. 1940. Plant succession as a result of grazing and of meadow desiccation by erosion since settlement in 1892. Journal of Forestry 38:613-626.

Dumroese, R.K., T. Luna, B.A. Richardson, F.F. KilKenny, And J.B. BunYon. 2015. Conserving and restoring habitat for Greater Sage-Grouse and other sagebrush-obligate wildlife: the crucial link of forbs and sagebrush diversity. Native Plants 16:276-299

Fiske, I., AND R. ChandLER. 2011. Unmarked: an R package for fitting hierarchical models of wildlife occur- rence and abundance. Journal of Statistical Software 43:1-23.

Freeman, E.D., T.R. Sharp, R.T. Larsen, R.N. Knight, S.J. Slater, and B.R. McMillan. 2014. Negative effects of an exotic grass invasion on small-mammal communities. PLOS ONE 9:e108843.

Fretwell, S.D., and H.L. LuCas. 1969. On territorial behavior and other factors influencing habitat distribution in birds. Acta Biotheoretica 19:16-36.

FreY, J.K. 2009. Distinguishing range expansions from previously undocumented populations using background data from museum records. Diversity and Distributions 15:183-187.

Gray, S.T., J.L. Betancourt, S.T. Jackson, and R.G. EDDY. 2006. Role of multidecadal climate variability in a range extension of pinyon pine. Ecology 87: $1124-1130$

Greenwood, P.J. 1980. Mating systems, philopatry and dispersal in birds and mammals. Animal Behaviour 28:1140-1162.

Grinnell, J., And T.I. Storer. 1924. Animal life in the Yosemite; an account of the mammals, birds, reptiles, and amphibians in a cross-section of the Sierra Nevada, by Joseph Grinnell and Tracy Irwin Storer. University of California Press, Berkeley, CA.

HaLl, E.R. 1946. Mammals of Nevada. University of California Press, Berkeley, CA.

Hoffmeister, D.F. 1951. A taxonomic and evolutionary study of the piñon mouse, Peromyscus truei. Illinois Biological Monographs 21:1-104.

Hoffmeister, D.F. 1981. Peromyscus truei. Mammalian Species 161:1-5.

Holbrook, S.J. 1978. Habitat relationships and coexistence of four sympatric species of Peromyscus in northwestern New Mexico. Journal of Mammalogy 59:18-26.

KnapP, P.A. 1996. Cheatgrass (Bromus tectorum L) dominance in the Great Basin Desert: history, persistence, and influences to human activities. Global Environmental Change 6:37-52.

KNICK, S.T., AND J.T. ROTENBERRY. 2000. Ghosts of habitats past: contribution of landscape change to current habitats used by shrubland birds. Ecology 81: 220-227.

Larrucea, E.S., and P.F. Brussard. 2008. Shift in location of pygmy rabbit (Brachylagus idahoensis) habitat in response to changing environments. Journal of Arid Environments 72:1636-1643.

LiNSDALE, J.M. 1938. Environmental responses of vertebrates in the Great Basin. American Midland Naturalist 19:1-206.

Miller, R.F., J.D. Bates, T.J. Svejcar, F.B. Pierson, and L.E. Eddleman. 2005. Biology, ecology, and management of western juniper. Oregon State University Agricultural Experiment Station, Technical Bulletin 152:77.

Miller, R.F., AND J.A. Rose. 1999. Fire history and western juniper encroachment in sagebrush steppe. Journal of Range Management 52:550-559.

Miller, R.F., T.J. SvejCar, and J.A. Rose. 2000. Impacts of western juniper on plant community composition and structure. Journal of Range Management 53: 574-585.

Miller, R.F., and R.J. Tausch. 2001. The role of fire in pinyon and juniper woodlands: a descriptive analysis. Pages 15-30 in K.E.M. Galley and T.P. Wilson, editors, Proceedings of the invasive species workshop: 
the role of fire in the control and spread of invasive species. Tall Timbers Research Station, Tallahassee, FL.

Miller, R.F., AND P.E. Wigand. 1994. Holocene changes in semiarid pinyon-juniper woodlands: responses to climate, fire, and human activities in the US Great Basin. BioScience 44:465-474.

MoRin, P.J. 1984. Odonate guild composition: experiments with colonization history and fish predation. Ecology 65:1866-1873.

Moritz, C., J.L. Patton, C.J. Conroy, J.L. Parra, G.C. White, and S.R. Beissinger. 2008. Impact of a century of climate change on small-mammal communities in Yosemite National Park, USA. Science 322:261-264.

MorRis, D.W. 1988. Habitat-dependent population regulation and community structure. Evolutionary Ecology 2:253-269.

Morris, D.W. 2011. Adaptation and habitat selection in the eco-evolutionary process. Proceedings of the Royal Society of London B: Biological Sciences 278:2401-2411.

MorRis, L.R., AND R.J. Rowe. 2014. Historical land use and altered habitats in the Great Basin. Journal of Mammalogy 95:1144-1156.

Noson, A.C., R.A. Schmitz, and R.F. Miller. 2006. Influence of fire and juniper encroachment on birds in high-elevation sagebrush steppe. Western North American Naturalist 66:343-353.

Noss, R.E., E.T. LaRoe III, and J.M. Scott. 1995. Endangered ecosystems of the United States: a preliminary assessment of loss and degradation. Biological Report 28. National Biological Service, Washington, DC.

NovaK, S.J., AND R.N. Mack. 2001. Tracing plant introduction and spread: genetic evidence from Bromus tectorum (cheatgrass). BioScience 51:114-122.

OsGoOD, W.H. 1909. Revision of the mice of the American genus Peromyscus. U.S. Department of Agriculture, Bureau of Biological Survey, North American Fauna 28:1-285.

Ostoja, S.M., And E.W. Schupp. 2009. Conversion of sagebrush shrublands to exotic annual grasslands negatively impacts small mammal communities. Diversity and Distributions 15:863-870.

Paulin, K.M., J.J. Cook, and S.R. Dewey. 1999. Pinyonjuniper woodlands as sources of avian diversity. Pages 240-243 in S.B. Monsen and R. Stevens, editors, Proceedings: ecology and management of pinyon-juniper communities within the Interior West. USDA Forest Service Proceedings, Ogden, UT.

Pavlacky, D.C., AND S.H. ANDERSON. 2001. Habitat preferences of pinyon-juniper specialists near the limit of their geographic range. Condor 103:322-331.

R Core Team. 2015. R: a language and environment for statistical computing. R Foundation for Statistical Computing, Vienna, Austria. http://www.R-project.org

Resetarits, W.J. 2005. Habitat selection behaviour links local and regional scales in aquatic systems. Ecology Letters 8:480-486.

Rickart, E.A., S.L. Robson, and L.R. Heaney. 2008. Mammals of Great Basin National Park, Nevada: comparative field surveys and assessment of faunal change. Monographs of the Western North American Naturalist 4:77-114.

Rodhouse, T.J., R.P. Hirnyck, AND R.G. WRIGHT. 2010. Habitat selection of rodents along a piñon-juniper woodland-savannah gradient. Journal of Mammalogy 91:447-457.

Rompola, K.M., and S.H. Anderson. 2004. Habitat of three rare species of small mammals in juniper woodlands of southwestern Wyoming. Western North American Naturalist 64:86-92.

Rosenzweig, M.L. 1981. A theory of habitat selection. Ecology 62:327-335.

Rottler, C.M., C.E. Noseworthy, B. Fowers, and J.L. BECK. 2015. Effects of conversion from sagebrush to non-native grasslands on sagebrush-associated species. Rangelands 37:1-6.

Rowe, R.J., J.A. Finarelli, and E.A. Rickart. 2010. Range dynamics of small mammals along an elevational gradient over an 80-year interval. Global Change Biology 16(11):2930-2943.

Rowe, R.J., AND R.C. TERRY. 2014. Small mammal responses to environmental change: integrating past and present dynamics. Journal of Mammalogy 95: 1157-1174.

Rowe, R.J., R.C. Terry, and E.A. Rickart. 2011. Environmental change and declining resource availability for small mammal communities in the Great Basin. Ecology 92:1366-1375.

Rowland, M.M., M.J. Wisdom, L.H. Suring, and C.W. MEInKE. 2006. Greater Sage-Grouse as an umbrella species for sagebrush-associated vertebrates. Biological Conservation 129:323-335.

RoYALL, R.M. 1997. Statistical evidence: a likelihood paradigm. Chapman and Hall, New York, NY.

Schupp, E.W., J.C. Chambers, S.B. Vander Wall, J.M. Gomez, and M. Fuentes. 1999. Piñon and juniper seed dispersal and seedling recruitment at woodland ecotones. Pages 66-70 in E.D. McArthur, W.K. Ostler, and C.L. Wambolt, editors, Proceedings: shrubland ecotones. U.S. Forest Service Proceedings RMRS-P-11.

Sikes, R.S., W.L. Gannon, and the Animal Care and Use Committee of the American Society of Mammalogists. 2011. Guidelines of the American Society of Mammalogists for the use of wild mammals in research. Journal of Mammalogy 92: $235-253$

Suring, L.H., M.J. Wisdom, R.J. Tausch, R.F. Miller, M.M. Rowland, L. Schueck, and C.W. Meinke. 2005. Modeling threats to sagebrush and other shrubland communities. Pages 114-149 in M.J. Wisdom, M.M. Rowland, and L.H. Suring, editors, Habitat threats in the sagebrush ecosystem: methods of regional assessment and applications in the Great Basin. Alliance Communications Group, Lawrence, KS.

Tausch, R.J., N.E. West, and A.A. NabI. 1981. Tree age and dominance patterns in Great Basin pinyonjuniper woodlands. Journal of Range Management $34: 259-264$

Terry, R.C. 2010. The dead do not lie: using skeletal remains for rapid assessment of historical smallmammal community baselines. Proceedings of the Royal Society B: Biological Sciences 277:1193-1201.

VANDER WALL, S.B. 1997. Dispersal of singleleaf piñon pine (Pinus monophylla) by seed-caching rodents. Journal of Mammalogy 78:181-191.

Vander Wall, S.B., AND R.P. BaLdA. 1981. Ecology and evolution of food-storage behavior in conifer-seedcaching corvids. Zeitschrift für Tierpsychologie 56: 217-242. 
VAN HoRne, B. 1983. Density as a misleading indicator of habitat quality. Journal of Wildlife Management 47:893-901.

Vonesh, J.R., J.M. Kraus, J.S. Rosenberg, and J.M. Chase. 2009. Predator effects on aquatic community assembly: disentangling the roles of habitat selection and post-colonization processes. Oikos 118:1219-1229.

Weisberg, P.J., E. Lingua, and R.B. Pillai. 2007. Spatial patterns of pinyon-juniper woodland expansion in central Nevada. Rangeland Ecology and Management 60:115-124.

Whisenant, S.G. 1990. Changing fire frequencies on Idaho's Snake River Plains: ecological and management implications. Page 4-10 in E.D. McArthur, E.M. Romney, S.D. Smith, and P.T. Tueller, editors, Proceedings-Symposium on cheatgrass invasion, shrub die-off, and other aspects of shrub biology and management, Las Vegas, NV, April 5-7, 1989. USDA Forest Service, Intermountain Research Station, Ogden, UT.

WiCKHAM, H. 2009. ggplot2: elegant graphics for data analysis. Springer, New York, NY.
Willis, M.J., AND R.F. Miller. 1999. Importance of western juniper communities to small mammals Pages 210-214 in S.B. Monsen and R. Stevens, editors, Proceedings: ecology and management of pinyon-juniper communities within the Interior West. USDA Forest Service Proceedings RMRS-P-9, Ogden, UT.

Wisdom, M.J., M.M. Rowland, AND L.H. SuRING, EDITORS. 2005. Habitat threats in the sagebrush ecosystem: methods of regional assessment and applications in the Great Basin. Alliance Communications Group, Lawrence, KS.

Yang, D.-S., C.J. Conroy, AND C. Moritz. 2011. Contrasting responses of Peromyscus mice of Yosemite National Park to recent climate change. Global Change Biology 17:2559-2566.

Received 30 August 2016

Accepted 2 October 2017 Published online 29 January 2018

APPENDIX 1. All 81 captured Peromyscus truei were prepared as voucher specimens and deposited in a natural history collection. The musuem collection and catalog numbers are given.

Nevada, Lander Co.: UMNH: 32794-32795, 32944, 33104-33107, 33209-33211, 33348-33350, 33593, 33692-33695, 34233, 34316-34317, 34358, 34448-34462, 34480-34481, 34493-34494.

Nevada, Nye Co.: UMNH: 33872-33873, 33876-33880, 33919, 33954-33956, 34071-34077, 34185-34186, 34632-34640, 34676; BYU: 33380-33381, 33801-33806; MVZ: 227168-227169.

APPENDix 2. Results of the detection models for occupancy and abundance. Predictor variables included trap effort (trapdays), Julian date $(j d)$ as a linear and quadratic function, and trend (trend) to account for removal trapping. $\mathrm{K}=$ number of parameters, $\mathrm{AIC}=$ Akaike information criterion, $\Delta \mathrm{AIC}=$ model $\mathrm{AIC}$ difference, $\mathrm{AIC}$ wt $=$ model Akaike weight.

\begin{tabular}{|c|c|c|c|c|}
\hline Occupancy models & $\mathrm{K}$ & $\mathrm{AIC}$ & $\Delta \mathrm{AIC}$ & AIC wt \\
\hline $\operatorname{psi}() p.($ trapdays + trend $)$ & 4 & 221.53 & 0.00 & 0.28 \\
\hline psi(.)p(trapdays $)$ & 3 & 221.67 & 0.13 & 0.26 \\
\hline psi(.)p(trapdays $+\mathrm{jd}+$ trend $)$ & 5 & 223.51 & 1.98 & 0.10 \\
\hline psi(.)p(trapdays + jd $)$ & 4 & 223.64 & 2.11 & $9.7 \times 10^{-2}$ \\
\hline $\operatorname{psi}(.) \mathrm{p}()$. & 2 & 225.31 & 3.77 & $4.2 \times 10^{-2}$ \\
\hline $\mathrm{psi}(.) \mathrm{p}\left(\right.$ trapdays $+\mathrm{jd}+\mathrm{jd}^{2}+$ trend $)$ & 6 & 225.46 & 3.92 & $3.9 \times 10^{-2}$ \\
\hline $\operatorname{psi}() p.(j d)$ & 3 & 225.53 & 4.00 & $3.7 \times 10^{-2}$ \\
\hline $\mathrm{psi}(.) \mathrm{p}\left(\right.$ trapdays $\left.+\mathrm{jd}+\mathrm{jd}^{2}\right)$ & 5 & 225.60 & 4.07 & $3.6 \times 10^{-2}$ \\
\hline $\mathrm{psi}(.) \mathrm{p}(\mathrm{jd}+$ trend $)$ & 4 & 225.97 & 4.44 & $3.0 \times 10^{-2}$ \\
\hline psi(.)p(trend) & 3 & 226.06 & 4.53 & $2.9 \times 10^{-2}$ \\
\hline $\mathrm{psi}(.) \mathrm{p}\left(\mathrm{jd}+\mathrm{jd}^{2}\right)$ & 4 & 226.16 & 4.63 & $2.7 \times 10^{-2}$ \\
\hline $\mathrm{psi}(.) \mathrm{p}\left(\mathrm{jd}+\mathrm{jd}^{2}+\right.$ trend $)$ & 5 & 226.51 & 4.98 & $2.3 \times 10^{-2}$ \\
\hline Abundance models & $\mathrm{K}$ & $\mathrm{AIC}$ & $\Delta \mathrm{AIC}$ & AIC wt \\
\hline$\overline{\operatorname{lam}(.) \mathrm{p}(\text { trapdays }+\mathrm{jd})}$ & 4 & 475.26 & 0.00 & 0.56 \\
\hline $\operatorname{lam}(.) \mathrm{p}$ (trapdays) & 3 & 477.13 & 1.87 & 0.22 \\
\hline $\operatorname{lam}(.) \mathrm{p}\left(\operatorname{trapdays}+\mathrm{jd}+\mathrm{jd}^{2}\right)$ & 5 & 477.19 & 1.93 & 0.21 \\
\hline $\operatorname{lam}(.) \mathrm{p}\left(\mathrm{jd}+\mathrm{jd} \mathrm{d}^{2}\right)$ & 4 & 486.26 & 11.00 & $2.3 \times 10^{-3}$ \\
\hline $\operatorname{lam}(.) \mathrm{p}()$. & 2 & 488.89 & 13.64 & $6.1 \times 10^{-4}$ \\
\hline $\operatorname{lam}(.) \mathrm{p}(\mathrm{jd})$ & 3 & 490.39 & 15.13 & $2.9 \times 10^{-4}$ \\
\hline
\end{tabular}


APPENDIX 3. Model set for occupancy and abundance analysis. Preliminary analyses indicated that the form of the relationship for elevation was a linear function for occupancy and a quadratic function for abundance. Aspect was converted to radians and then cos- and sintransformed to yield northness and eastness, respectively.

Model

(.)

pj

woody cover

elevation

slope

aspect

year

$\mathrm{pj}+$ woody cover + elevation + year + slope + aspect

$\mathrm{pj}+$ woody cover + elevation + year

$\mathrm{pj}+$ woody cover + elevation

pj + woody cover + year

$\mathrm{pj}+$ woody cover + slope

pj + woody cover

$\mathrm{pj}+$ elevation

$\mathrm{pj}+$ slope

elevation + slope + aspect

elevation + aspect

elevation + year

elevation + woody cover 